2009s-10

\title{
Entrepreneurial Equity \\ Financing and Securities Regulation: An Empirical Analysis
}

\author{
Cécile Carpentier, Jean-Marc Suret
}

\begin{tabular}{c}
\hline Série Scientifique \\
Scientific Series
\end{tabular}

\section{Montréal}

Avril 2009

(version mise à jour en février 2010)

(C) 2009 Cécile Carpentier, Jean-Marc Suret. Tous droits réservés. All rights reserved. Reproduction partielle permise avec citation du document source, incluant la notice (C).

Short sections may be quoted without explicit permission, if full credit, including (C) notice, is given to the source.
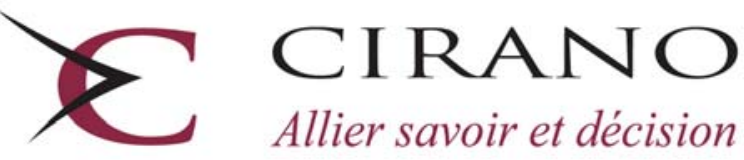

Allier savoir et décision

Centre interuniversitaire de recherche en analyse des organisations 


\section{CIRANO}

Le CIRANO est un organisme sans but lucratif constitué en vertu de la Loi des compagnies du Québec. Le financement de son infrastructure et de ses activités de recherche provient des cotisations de ses organisations-membres, d'une subvention d’infrastructure du Ministère du Développement économique et régional et de la Recherche, de même que des subventions et mandats obtenus par ses équipes de recherche.

CIRANO is a private non-profit organization incorporated under the Québec Companies Act. Its infrastructure and research activities are funded through fees paid by member organizations, an infrastructure grant from the Ministère du Développement économique et régional et de la Recherche, and grants and research mandates obtained by its research teams.

\section{Les partenaires du CIRANO}

\section{Partenaire majeur}

Ministère du Développement économique, de l’Innovation et de l’Exportation

\section{Partenaires corporatifs}

Banque de développement du Canada

Banque du Canada

Banque Laurentienne du Canada

Banque Nationale du Canada

Banque Royale du Canada

Banque Scotia

Bell Canada

BMO Groupe financier

Caisse de dépôt et placement du Québec

DMR

Fédération des caisses Desjardins du Québec

Gaz de France

Gaz Métro

Hydro-Québec

Industrie Canada

Investissements PSP

Ministère des Finances du Québec

Power Corporation du Canada

Raymond Chabot Grant Thornton

Rio Tinto Alcan

State Street Global Advisors

Transat A.T.

Ville de Montréal

\section{Partenaires universitaires}

École Polytechnique de Montréal

HEC Montréal

McGill University

Université Concordia

Université de Montréal

Université de Sherbrooke

Université du Québec

Université du Québec à Montréal

Université Laval

Le CIRANO collabore avec de nombreux centres et chaires de recherche universitaires dont on peut consulter la liste sur son site web.

Les cahiers de la série scientifique (CS) visent à rendre accessibles des résultats de recherche effectuée au CIRANO afin de susciter échanges et commentaires. Ces cahiers sont écrits dans le style des publications scientifiques. Les idées et les opinions émises sont sous l'unique responsabilité des auteurs et ne représentent pas nécessairement les positions du CIRANO ou de ses partenaires.

This paper presents research carried out at CIRANO and aims at encouraging discussion and comment. The observations and viewpoints expressed are the sole responsibility of the authors. They do not necessarily represent positions of CIRANO or its partners. 


\title{
Entrepreneurial Equity Financing and Securities Regulation: An Empirical Analysis*
}

\author{
Cécile Carpentier ${ }^{\dagger}$, Jean-Marc Suret ${ }^{\ddagger}$
}

\begin{abstract}
Résumé / Abstract
La réglementation des valeurs mobilières interdit généralement l'accès au marché boursier des entreprises en démarrage, afin de protéger les investisseurs. Des universitaires et les organismes de réglementation prétendent que des règles strictes et des exigences fortes sont nécessaires pour éviter l'échec du marché. Toutefois, ces contraintes peuvent limiter de façon exagérée les possibilités de croissance des entreprises émergentes. Nous exploitons la situation très particulière du Canada pour étudier l'effet du relâchement des contraintes réglementaires. Dans ce pays, les entreprises émergentes peuvent entrer en Bourse au moyen de prises de contrôle inversées, alors qu'elles ne rapportent pas de revenus et présentent une capitalisation minime. Elles peuvent même échapper à l'obligation de préparer un prospectus. Cette situation permet d'étudier des entrepreneurs inscrits sur un marché public d'actions. La qualité des entreprises, de même que leur performance après l'accès en Bourse et leur stratégie de financement sont cohérente avec la proposition qui veut que le relâchement des règles permet l'émergence d'un marché d'entreprises de mauvaises qualités, un lemon market. Les investisseurs, qui subissent des rendements anormalement faibles, ne semblent pas être en mesure d'apprécier correctement la valeur des émetteurs ni de gérer les importants problèmes liés à l'asymétrie informationnelle dans ce contexte. Les réticences de la majorité des organismes de réglementation à baisser les normes minimales d'inscription semble don bien être justifiée.
\end{abstract}

Mots clé : réglementation des valeurs mobilières, entrepreneurs, entreprises émergentes, émissions d'actions, prise de contrôle inversée, politique publique.

To protect investors, securities regulation generally restrains entrepreneurial ventures from entering the stock market. Scholars and regulators contend that strong rules and requirements for listing are essential to prevent the market from failing. However, these constraints can also unduly impede the growth of new ventures. We use the Canadian case to examine the effects of the relaxation of the regulatory constraints. Unlike in other countries, firms in Canada can list at a very early stage, without revenues, with a minimal size and even without writing a prospectus using the reverse merger technique. This provides a unique opportunity to examine entrepreneurial ventures listed on a public market. The quality of firms, their post-listing operating performance and strategy, and their fate largely support the opinion that strong listing requirements are essential to prevent the emergence of a lemon market. Investors involved in this market obtain very poor returns. This indicates that they are neither able to set correct prices in this market nor to deal with the high level of information asymmetry therein. The reluctance of most regulators to relax the requirements for small business finance can therefore be justified.

Keywords: securities regulation, entrepreneurial ventures, equity financing, reverse takeover, public policy.

Codes JEL: G30, G32, L21, O16.

\footnotetext{
* The authors thank the Fonds réservé de l’Autorité des marchés financiers du Québec (the "Autorité") and SSHRC for financial support. The comments and opinions expressed by the authors of this article do not necessarily reflect the opinion of the Autorité. The authors thank Bruno Lamy and Serge Dumais for valuable research assistance.

${ }^{\dagger}$ Professor, Laval University and CIRANO Fellow, Faculty of Administrative Science, School of Accountancy.

${ }^{\ddagger}$ Corresponding author: Professor, Laval University and CIRANO Fellow, Faculty of Administrative Science, School of Accountancy, Pavilion Palasis-Prince, 2325 de la Terrasse, Laval University, Québec (Québec) Canada, G1V 0A6, phone: 418656 7134, fax: 418656 7746, email: Jean-Marc.Suret@fsa.ulaval.ca.
} 


\section{INTRODUCTION}

The aim of this paper is to analyze the economic consequences of relaxing the constraints that prevent small and medium-sized enterprises (SMEs) from accessing the stock market at an early stage of development. Securities regulators have to balance their role in facilitating legitimate capital formation for small issuers with that of protecting public investors. To reach this second objective, the stock exchanges generally set minimum requirements that prevent an emerging business from listing. The securities regulations usually demand that a prospectus be produced. The resulting time and expenses required make it difficult for small businesses to launch the initial public offering (IPO) needed to enter the stock market.

In an attempt to contribute to the debate between the pros and the cons of easing financial regulation for SMEs, we examine the very particular situation that prevails in Canada. In this country, new ventures can access the stock market at a pre-revenues stage with a minimal capitalization of a few hundred Canadian dollars. They also do not need to comply with the conventional IPO process. Indeed, new ventures can list using a "backdoor listing" method, namely a reverse merger (RM or reverse takeover). Whereas securities laws are generally viewed as having an enormous impact on the ability of start-up companies to obtain equity finance, there is sparse empirical evidence of the real effects of regulatory constraints. As mentioned by Cohn (1999, p. 365), statistical evidence does not exist regarding the extent to which small and developing companies have been impeded by federal and state securities laws from raising capital in a timely and sufficient manner. Finding the right balance between investor protection and the financing of new ventures is a worldwide concern (Friedman and Grose, 2006). The creation of numerous stock markets devoted to emerging firms, the introduction of alternative listing methods, the increasing proportion of private versus public placements by small listed companies, and the discussions about the proportionate regulation and the regulation of private placements illustrate the importance of the debate surrounding the regulation of small business equity financing.

Access to finance is an important growth constraint for SMEs (Beck and Demirguc-Kunt, 2006). Equity finance is generally associated with the success of new ventures (Shane, 2003), and providing access to the public market is often considered a means of relaxing the financing constraints faced by small businesses (Kim, 1999). According to small business advocates, ${ }^{1}$ entrepreneurs' ability to develop their business is unduly constrained by securities regulation (Cohn, 
1999; Moller, 2000; Rousseau, 2000; Cohn and Yadley, 2007). This vision is also largely present among practitioners and politicians. The president of the U.S. Congress sub-committee opened the hearings on the role of the Securities and Exchange Commission (SEC) in capital formation ${ }^{2}$ by stating: I am greatly distressed by the concerns that fundamental regulatory obstacles are inhibiting the flow of capital to and investor participation in the small and middle market business sector. In the same vein, Huffman (2000, p.307) argues that the past century of regulation has significantly disadvantaged small and emerging business relative to big and established business, resulting in significant losses in innovation and economic productivity. This perspective implicitly assumes that easing the regulation for smaller issuers will not harm investors. Even if they call for significant changes in favor of small businesses, Cohn and Yadley (2007, p.72) wrote that no one would argue that the SEC should undermine investor protection in favor of liberalizing the capital formation opportunities of small companies.

Eminent researchers in law and economics propose an opposite point of view. They consider that strong regulation, mainly governing IPOs, is a prerequisite to the establishment of a sound equity market (Black, 2001; La Porta et al., 2006). Security issuance is subject to the promoter problem that leads entrepreneurs to sell bad securities to the public (Mahoney, 1995). Individual investors are not skilled enough to deal with the large information asymmetry that prevails for entrepreneurial ventures and cannot correctly assess the value of these firms. Strong minimum listing requirements thus become a "necessary safeguard" for investors. In this paper, we examine three implications of this perspective, using the particular context of very low regulatory requirements. First, according to the regulators' perspective, a market with low listing requirements and lax regulation becomes a "lemon" market. ${ }^{3}$ Second, in such a market, managers list for reasons other than financing new projects. Third, because individual investors cannot correctly assess the value of entrepreneurial firms, they earn low returns and experience high loss probability.

Our paper is one of the first to analyze the financing of new ventures through the stock market. The literature about penny stocks IPOs and backdoor listing is indeed limited to a few papers that study "small firms" that cannot be considered entrepreneurial ventures. ${ }^{4}$ We use a much larger sample of RMs than previous studies, and examine a period of two decades. We also contribute to the debate surrounding the nature of the equity gap. The observation of firms that do not face significant constraints to access a stock market can indeed indicate the extent that the frequently reported 
equity financing problem is due to a lack of investment readiness (Mason and Harrison, 2001; 2002) or to other demand side effects (Howorth, 2001). We also provide evidence of the capacity of individual investors to wisely invest in emerging firms.

The remainder of the paper is structured as follows: Part 1 discusses the specific features of the Canadian stock market and the RM process. Part 2 discusses the perspectives on the regulation and small business finance and presents our propositions. Part 3 presents the data sources and stylized facts. We test the propositions linked with the operational dimensions and the fate of the resulting companies in Part 4, and analyze the post-listing financing activity in Part 5. We discuss the methodology of measuring market performance and our results in Part 6. Part 7 concludes the paper.

\section{The CANADIAN LISTING REQUIREMENTS AND THE RM PROCESS}

The Canadian stock exchange applies very lax initial listing requirements. For a listing on Tier 2 of the TSX venture exchange (TSXV), a firm must have a stock price over CAN\$0.15 and post-IPO net tangible assets and market capitalization higher than CAN\$500,000. The TSXV has no requirements related to issuers' profitability. As a result, the pre-listing median shareholders' equity of newly listed companies from 1986 to 2006 is CAN\$260,000, and more than 80\% of firms report negative earnings (Carpentier et al., 2009). Entrepreneurial ventures can enter the Canadian stock market, whereas they cannot access any other junior markets. ${ }^{5}$ They can also bypass the IPO process, using RM listing.

An RM listing follows a merger between a public shell company, which is generally inactive, and an operating privately held company. Figure 1 illustrates a typical shell with a very low market value: CAN\$100,000, composed of 500,000 shares priced at CAN\$0.20. Operating closed firms seeking listing usually have a higher value: for example 500,000 shares priced at CAN\$1. The resulting company, named Result inc., comes from the merger of the two former firms, which entails an exchange of shares. The difference in value between the shell and the operating company implies that the shareholders of the private operating company acquire the majority of the shares of the resulting entity. This transaction is called an RM because the shareholders of the private company ultimately control the public company. RM listings are exempt from filing a prospectus

and need not comply with the registration requirements prevailing for IPOs. ${ }^{6}$ During an RM, the company cannot issue equity publicly, because these transactions are not considered public 
offerings. The new venture obtains the cash available in the shell, and often issues a private

placement. ${ }^{7}$ As a result, the private company becomes public by buying the shell but avoids filing a prospectus, selling new shares to the public and meeting the minimum listing requirements. "Classic" shells are once active companies that failed to develop and ceased or strongly reduced their activities, but have kept their status of public company. "Manufactured" shells are created specifically from zero, using the Capital Pool Company (CPC) program (Carpentier and Suret, 2006). We restricted this study to the analysis of transactions involving classic shells, for the sake of generality. RMs on classic shells exist in several countries.

**Insert Figure 1 about here**

According to the firms specializing in RMs, the primary benefits of going public this way are the significantly lower costs and less time required for an RM than for an IPO. ${ }^{8}$ Gleason et al. (2005) estimate that IPOs take a minimum of 6 months while RMs take between 1 and 3 months. In addition, RMs involve substantially lower costs than IPOs. ${ }^{9}$ Feldman (2009) adds less dilution and escaping to the underwriter requirement to the advantages of RMs.

\section{THE TWO PERSPECTIVES ON SECURITIES REGULATION AND ENTREPRENEURIAL FINANCE}

The entrepreneurial process is generally defined as a process leading to new firm creation and development, and entails recognizing the value of opportunities, collecting resources and exploiting them for economic success (Shane and Venkataraman, 2000; Shane, 2003). The literature acknowledges that the acquisition of external resources can be impeded by opportunism, excessive risk taking and adverse selection (Shane, 2003, p.165). However, small business advocates contend that financial regulation, which imposes costs and restrictions on SMEs, unduly impedes this entrepreneurial process. The regulators' perspective underlines the promoter's willingness to exploit information asymmetry to transfer wealth from outside investors. For this reason, the regulators impose strict requirements for gaining access to the public market and consider that the financing of emerging businesses should be assumed by specialized investors. However, we contend that the main difference in the perspectives is their view of the investor's rationality and skills.

\subsection{The SMALl Business AdVOCATES’ PERSPECTIVE}

Emerging companies, especially those that are new technology based, are financially constrained (Westhead and Storey, 1997; Beck and Demirguc-Kunt, 2006). This constraint is assumed to have 
negative economic consequences. Carpenter and Petersen (2002, p.307), among others, show that the growth of most small firms is constrained by the availability of internal finance while the small fraction of firms that make heavy use of new share issues exhibit growth rates far above what can be supported by internal finance. The availability of external funding is thus a crucial determinant for economic development (Becchetti and Trovato, 2002), survival, growth and profitability of entrepreneurial ventures. ${ }^{10}$

To fill the assumed equity gap for emerging businesses, several countries have attempted to implement specialized stock markets or specific segments of the main markets, generally known as new, SME or junior markets. By the end of 2008, the World Federation of Exchanges listed 34 markets in this category worldwide. However, the creation of markets dedicated to emerging firms has been contemplated by more countries. Posner (2009, pp.4-5) lists 53 proposals for smaller companies stock exchanges in European countries from 1977 to 2005. Accordingly, the economic implications of providing emerging companies with access to stock markets is a timely and important topic.

Even on the junior markets dedicated to emerging companies, accessing a stock market through a conventional IPO is a long and costly process. The exchanges' minimum listing requirements are a formidable barrier for new companies in most developed markets. Indeed, Shane (2003) considers the achievement of an IPO a measure of entrepreneurial performance. Several authors have become small business advocates. They contend that the securities regulation should be changed to ease the financing of emerging businesses. Chiu (2004, p.933) concludes that Europe should consider the modification of its one-size-fits-all mandatory disclosure rules in securities regulation and adopt a tiered disclosure regime based on issue size (...) in order to facilitate small business access to the public equity markets. Cohn (1999) illustrates this opinion by citing the many rules that the Wright Brothers would have had to follow had they attempted to start their business in the 1990s in the U.S., and concludes that they would probably not have gotten off the ground because of the complexity and the weight of the securities regulations. Cohn and Yadley (2007) consider the SEC's continuing failure to address small business financing concerns as a "capital offense." In Canada, Rousseau (2000) contends that the Canadian regulatory framework is inadequate to allow SMEs access to public equity financing.

The reasoning of small business advocates can be summarized as follows. First, there are negative economic consequences to the financing constraints faced by emerging businesses. Second, the 
stock market is a source of equity finance, with lower limitations and costs than the venture capital sources. As Cohn (1999) asserts, the equity provided by a stock exchange is permanent, while the venture capital is provided only for a limited period. Third, the negative effects of easing the regulation for SMEs are generally not considered material. Individual investors, who generally invest in smaller issues, are implicitly assumed to be rational and skilled enough to assess the risks of such firms and to price them correctly. When these conditions are met, individual investors can expect a fair rate of return.

This reasoning offers a rationale for the easing of the listing requirements, and the implementation of proportionate regulation ${ }^{11}$ including the promotion of backdoor listings examined in this study. First, this listing method offsets the high costs of entering the market and requires less time and effort from management. Second, an RM allows firms that do not meet the minimum listing requirements to list. Third, an RM can be included in a financing strategy. After the RM, the stock trading allows a price to be set by the market, before any public placement. In the U.K., a number of firms list without issuing equity and then do so shortly thereafter. Derrien and Kecskes (2007) argue that this two-stage offering strategy is less costly than an IPO because trading reduces the valuation uncertainty of these firms before they issue equity. RM listings are becoming more prevalent in the U.S., where numerous foreign firms use this method to list. Chinese firms represent the bulk of these foreign RM users in the U.S. (Floros, 2008). RM listing is also present in the U.K. (Roosenboom and Schramade, 2007) and in several Asian countries. The U.S., the U.K. and Canada have implemented programs to encourage the creation of shells, which eases RM listing. On the $\mathrm{AIM}$, the Investment Companies can be considered equivalent to the $\mathrm{CPC}$, although they must raise a minimum of $£ 3$ million in cash. In the U.S., the Special Purpose Acquisition Companies (SPACs) are similar to CPCs, but for large transactions (Berger, 2008; Jenkinson and Sousa, 2009).

A totally opposite perspective is put forth by the authors that acknowledge the significance of the problems implicit in the large information asymmetry prevailing between the owners of new ventures and outside investors.

\subsection{THE REGULATORS’ PERSPECTIVE}

Asymmetric information is a critical barrier between issuers of common shares and public investors. The superior knowledge that the entrepreneur has about the firm creates a possibility for opportunistic behavior that puts the investor's money at risk. The informational disadvantage of 
outside investors is particularly severe for young innovative firms. The agency problem is most substantial for a newly formed company selling shares to the public for the first time. According to Mahoney (1995), the promoter may wish to channel the profit-making opportunities identified. This creates the promoter problem. Black (2001, p.7) advances that this problem is especially serious for small companies and companies that are selling shares to the public for the first time. For these companies, investors can't rely on the company's prior reputation to signal the quality of the information that it provides. In economic jargon, securities markets are a vivid example of a market for lemons. For Black, if the regulatory requirements are not strong enough, entrepreneurs and other insiders involved in the venture will have an incentive to exploit the investors' confidence. Dishonest entrepreneurs will become dominant, because they can sell stocks above their true but unknown value. Without the implementation of sound listing requirements, disclosure rules and the involvement of reputable intermediaries, the market will lead to a lemon equilibrium where only firms of poor quality list. Klausner and Litvak (2001, p.55) address a very similar point, and conclude that the anticipation of the lemons dynamic prevents the formation of a market for entrepreneurial finance from the outset. If, as proposed by Mason and Harrison (2002), there is a shortage of "investment ready" new ventures, the proportion of new good quality listed companies will be particularly low, and the promoter problem will be more acute.

Another strand of literature posits a similar proposition of a lemon equilibrium. Good firms with strong growth opportunities prefer to use venture capital for two main reasons. First, they can benefit from advice, contacts and monitoring. Second, they signal their quality to potential private investors. The choice of an RM can be driven by the willingness to escape a rigorous due-diligence process and the control implicit in venture capital contracts. Similarly, the choice between an IPO and an RM can also be influenced by signaling and costs considerations. The best firms can choose public offerings because they can reduce their cost of capital by increasing their liquidity or because their level of information asymmetry is lower (Chen et al., 2010). However, in a strongly regulated market, the Canadian RM firms should be unable to list and to offer their stocks to investors.

Accordingly, our first proposition is that the firms that use the backdoor listing methods are generally of poor quality (lemons). More specifically, they should exhibit:

1a) Poor financial characteristics at the listing time

1b) No improvement in operating performance after the RM 
1c) Low survival rate

A second direct implication of the promoter problem is that firms list for the wrong reasons. It is generally assumed that firms go public to finance future investments and growth or to reduce their cost of capital. From the regulators' perspective, high asymmetry of information and low regulatory requirements will prompt managers to go public to sell overvalued equity. Our second proposition is that RM firms do not go public to finance future investments and growth. More formally, we expect:

2) RM-listed firms exhibit little post-listing financing activity

The creation of a market for low quality firms is justifiable if two conditions are met. The first is that this low quality market must be clearly segmented from the main market. This enables the investors to assess the quality of the issuers based on the quality of the market. The second condition is that investors must be able to deal with very high information asymmetry and the promoter problem. They must be able to correctly assess the probability of success/failure of new listed firms. In addition, they must be able to set a correct price for newly listed companies, by adjusting the suggested prices for the lemon discount. However, specialists in venture capital and private equity stress that individual investors do not have the skill and tools required to deal with high information asymmetry (Fenn et al., 1997). Emerging businesses present huge valuation challenges. Investors can rely neither on past market data nor on the valuation ratio of comparable firms to appraise the fair value of the RM firms. Nor can they assess the value of firm assets, because most of these assets are intangible. In the majority of cases, negative returns on assets (ROA) and returns on equity (ROE) impede comparability, which is an important element of the valuation process. Even skilled business valuators face huge problems and give diverging values for emerging firms (Carpentier et al., 2008). From the regulators' perspective, strong minimum listing requirements thus become a "necessary safeguard" for investors that cannot invest wisely in this type of firm. ${ }^{12}$

In the U.S., regulatory actions have been largely influenced by these assumptions. The Penny Stock Reform Act of 1990 (PSRA), an attempt to curb fraudulent security issues, placed severe restrictions on IPOs that were priced below US\$5 and were generally issued by the smaller firms. The Sarbanes-Oxley Law (2002) is generally credited with having unintended consequences on small businesses, because of the high relative costs of complying with its new requirements. 
Recently, the SEC has adopted rules to further regulate public shells used in RM listings. In line with Black's argumentation, our third proposition is as follows:

3) The rate of return of investors involved in RM listings is abnormally low.

\subsection{PREVIOUS STUDIES}

To our knowledge, the academic literature on the performance of RM listings is limited to a few papers that study the U.S. market. Gleason et al. (2005) conducted an explanatory study of 121 RMs, largely concentrated during the technology bubble. They focus on the operational characteristics and effects of the RM announcements on the stock market. The resulting companies report median assets (capitalization) of US\$24.49 million (US\$33.10 million) but negative and decreasing ROA and ROE. 53.7\% of RM-listed companies disappear in the two years following the listing. For Gleason et al., RMs generally involve lower quality firms. In a second paper based on the same sample, Gleason et al. (2006) provide estimations of the long-run stock returns following RMs and compare these listings with self-underwritten IPOs. The authors find that when they go public, firms that use alternative mechanisms are less profitable than contemporaneous IPO firms of comparable size in the same sector. Two years after going public, they have significantly increased debt, and experience declines in profitability and balance sheet liquidity. Adjei et al. (2007) show that RM users are smaller, younger and have poorer performance on average than IPO users. Fortytwo percent of firms resulting from RMs are delisted within three years. Only $1.4 \%$ of their RM sample does not meet the initial listing requirements of any exchange. They conclude that the inability to list is not a motivation in choosing RM. Using a larger sample of 408 RMs, Floros and Shastri (2009) compare penny stock IPOs and RM listings in the U.S. They conclude that RMs are small, have low profitability, are in the development stage with limited operating history, and plan high research and development expenditures.

A related field of research is devoted to the junior markets whose lenient listing requirements allow younger companies to list (Martin, 2001; Bottazzi and Da Rin, 2002; Mahérault and Belletante, 2004). These papers generally consider these markets to have failed. Recently, Locke and Gupta (2008, p.89) analyze the recently created New Zealand Alternative Exchange, and find that the returns on the portfolio of entrepreneurial companies appear to be less than those for other small companies and for the market overall. This result is consistent with the regulators' perspective we present above. The London AIM is generally considered a successful exception (Posner, 2009), 
where the survival rate is in line with the one observed in North America (Espenlaub et al., 2010). However, most of the previous literature does not deal with true entrepreneurial ventures.

\section{DATA AND STYLIZED FACTS}

\subsection{SOURCES}

RM listings in Canada are not available in any database. To construct an accurate list of RMs associated with new listings, we used four sources. The first is the RM section of the monthly reviews of TSXV, available since 2001. Second, to detect RMs before 2001, we used a key word search programmed on all the fields of the accounting database (Thomson's Cancorp Financials). We then analyzed each of the mentions of RM, reverse takeover and associated terms to determine the cases where this operation was indeed associated with a new listing. Third, we scanned a stock market database (Datastream) to track the typical pattern of shells involved in an RM: a penny stock increases sharply in value for a few months before a trade suspension, and trading generally restarts under a new symbol. The fourth step entailed scanning the Canadian business newspaper databases (via Factiva and Eureka.cc) to identify all mentions of RM or reverse takeover. We cross-checked these four methods of detection, and we ascertained that the detected cases indeed consist of RMs associated with new listings. We detected a total of 892 RM new listings from 1988 to 2006, for which we identify the shell, the entrant and the resulting companies, using SEDAR ${ }^{13}$ and several Internet search tools. We extracted the accounting data from successive versions of Thomson's Cancorp Financials and from SEDAR. We obtained this information for $75.34 \%$ of the shells and $68.27 \%$ of the resulting companies. Accounting data related to the entrant companies are generally unavailable because of their private status before the merger, but the analysis of all the proxies sent to the shell shareholders provides sufficient information in 283 cases $(31.73 \%)$.

Several companies make a private placement several weeks or months after the listing. The new placements were tracked in SEDAR or in the Financial Post databases of new issues, the press releases, the Management Proxy Circular and the financial statements for each resulting company. In addition, we collected all the information about the financing activity of the newly listed companies from the FPinfomart.ca database, including private placements and public offerings, from the RM to the end of 2006. We carefully analyzed two series of returns for each RM. The first series comprises the returns of the shell and the second includes those of the resulting company. When a series of returns ceases before the end of our period of analysis, we investigate the causes 
and circumstances of this delisting. We analyze each case of acquisition to determine the acquisition price or, for an exchange of stocks, the values of the shares obtained by the former shareholders.

\subsection{STYLIZED FACTS}

RMs represent about $50 \%$ of conventional new listings in Canada, ${ }^{14}$ with an average frequency of 47 RMs per year from 1988 to 2006. Resulting companies generally do not obtain significant amounts of cash from investors at the listing time. The median gross proceeds of the private placements surrounding the listing are CAN\$0.75 million, and $31.50 \%$ of the resulting companies do not raise any funds. However, the proceeds increase during our analysis period, from CAN\$450,000 at the beginning of the 1990s to CAN\$2.10 million between 2001 and 2006. The proportion of RMs without financing fell sharply from $71.34 \%$ in the 1980 s to $5.10 \%$ at the beginning of the 2000s (Table 1). This pattern is probably associated with the sharp increase in resource prices since 2000, because most of the RM users are resource-based companies. RMs are concentrated in a few sectors: oil and gas (16.4\%), minerals (25.7\%), technologies (17.5\%) and services (19.7\%). Since 2001, the first three sectors have represented $79.2 \%$ of Canadian RMs.

In Table 2, we refine the analysis of fundraising around RMs. Only a small proportion of the resulting companies (16.14\%) raised amounts higher than CAN\$5 million. The proportion of RMs actually associated with the financing of significant growth opportunities is very low. The median gross proceeds are lower than CAN\$1 million. We detect two very large placements of more than CAN\$100 million. Only a very small minority of users of the RM listing method have significant investment projects to finance, even though all users seek external funding.

Many companies do an RM with gross proceeds of CAN\$0. We cannot determine in each case what drives these listings, because the information about these transactions is limited in recent years, and generally nonexistent before the implementation of SEDAR in 1997 . We analyzed the 41 cases with available information, which represents $14.6 \%$ of the RMs without gross proceeds. We conducted in-depth analysis to determine why some firms list without issuing equity. In 15 cases, the resulting firm appears to be unable to get money because its financial conditions deteriorate sharply after the RM. Two of these private placements failed and the others have been delayed. In the second group of 16 firms, the private placement has been done by the private firm before the RM. Such situations cannot be easily detected because private firms do not disclose any financial information in Canada. 
In two cases, the shell is not empty and the entrant firm finds enough cash in it to finance its activities. Overall, $20 \%$ of shells can be considered active firms and can provide some cash to the private firm. This left us with only 8 cases out of 41 where we cannot explain why the RM is not associated with a private placement.

**Insert Tables 1 and 2 about here**

\section{THE "LEMON" HYPOTHESIS}

We consider that firms can be viewed as lemons if they present three characteristics. They exhibit poor financial characteristics at the listing time (proposition 1a), they fail to improve their operating performance after the RM (proposition 1b), and their survival rate is low (proposition 1c). We begin by analyzing propositions $1 \mathrm{a}$ and $1 \mathrm{~b}$ that entail the challenging task of analyzing the operational performance surrounding RMs. Measuring the performance is complicated by the involvement of three entities: the shell, the entrant company and the resulting company.

\subsection{FINANCIAL CHARACTERISTICS AT LISTING TIME}

Table 3 (Panel A) shows that shell companies are micro-capitalization corporations with median total assets (shareholders' equity) of CAN\$0.36 million (CAN\$0.14 million). Non-operating companies represent $67.26 \%$ of the sample. The majority of shell companies report losses. Approximately one quarter of the shells reports revenues but negative earnings. A small proportion (7.89\%) of shells is active and profitable, with a median ROE of $14.13 \%$. They report median total assets of CAN\$1.65 million and median shareholders' equity of less than CAN\$1 million.

Panel B of Table 3 reports the characteristics of the entrant companies, namely the entrepreneurial ventures. They are very small firms, with median assets (shareholders' equity) of CAN\$1.27 million (CAN\$0.35 million). We can group these companies into three categories. Forty percent of entrant companies report no revenues and significant annual losses of CAN\$0.16 million. The median loss represents more than $50 \%$ of shareholders' equity, and their life expectancy without a cash injection can be expressed in months. A second group (36\% of the sample) reports both revenues and losses. For this group, total assets are higher than in the first category (median of CAN\$1.94 million), but shareholders' equity is merely CAN\$0.26 million. Their median loss is CAN\$0.62 million, and the life expectancy of these companies is also very short. Less than a quarter of entrant companies are profitable, although they are micro-capitalization companies with 
median assets (shareholders' equity) of CAN\$2.83 million (CAN\$0.63 million). The median ROE is $19.75 \%$. This high value is very likely explained by the small size of equity. Statistics Canada defines an SME as any business establishment with 0 to 499 employees and less than CAN\$50 million in revenues. We estimate that about $2 \%$ of private firms using RM in Canada are not SME in the strict sense. Most of the RM-listed companies can be considered new ventures. ${ }^{15}$

Table 4 describes the adjusted ROA and ROE, estimated as follows. First, we purged the Canadian universe of firms included in the Cancorp Financials database by omitting companies listed via an RM for the three years following the RM. From this sample, we then estimated the median of the ratio for six size groups (estimated by the book value of equity) and by sector (2 SIC digits). The abnormal performance of a firm is estimated by its raw return minus the median ratio of its size and sector matching group. To calculate the raw return, we used the data of the entrant companies, and when these data were not available, we use the data of the resulting company for the first year after the RM. Table 4 shows that the operating companies involved in RM have a worse performance (estimated by ROE and ROA) than comparable firms in industry and size, and that this difference is statistically significant.

Our analysis of RM listings thus presents a paradox: most of the entrant companies report no earnings, and several of them are still in the development stage and report no revenues. They appear strongly financially constrained, and the tiny capitalization of the shell cannot supply enough funds for enduring operations. Nonetheless, only a small proportion of newly listed companies issue significant gross proceeds around the listing time. The private placements issued by RM firms do not contribute to establishing a liquid market for the stock that can reduce the cost of equity and ease subsequent offerings. These observations, added to the extremely poor operating performance of the majority of the entrant companies, are consistent with proposition 1a, namely that RM firms can be considered low quality companies based on their operating performance.

**Insert Tables 3 and 4 about here**

\subsection{POST-LISTING OPERATIONAL PERFORMANCE}

In Table 5, we report the operational characteristics of the resulting companies for the three years following the RM. For comparison purposes, we also report the corresponding values for the entrant companies before the listing, adjusted for the main characteristics of the shell. As several shells are active companies, we add the data for the shell to those of the corresponding entrant company to 
provide a valid base of comparison with the resulting company. Even after the merger between the shell and the private company, the companies resulting from RMs in Canada are still microcapitalization companies. Their median shareholders' equity is CAN\$1.83 million. The resulting companies are poor performers. The proportion of negative earnings is $80.30 \%$ after the RM, and $33.66 \%$ of the newly listed companies report no revenues. The median ROE is $-20.12 \%$.

Operating performance fails to improve after the listing. Because several companies disappear in the first few years following the RM, we report the post-RM operating performance indicators for the whole sample and for a constant sample composed of the surviving firms for which accounting data are available in times 0 and 3. We also test for differences between the distributions of continuous variables using the Wilcoxon rank test and between the proportions (for the dummy variables) using a $\mathrm{Z}$ test. For the whole sample, median revenues increase significantly but the proportion of companies reporting no revenues increases slightly, from $33.66 \%$ to $34.47 \%$, three years later. This change is not significant. The proportion of negative earnings decreases, but this change is not significant. At the end of the third complete financial year following the RM, 78.42\% of RM firms report negative earnings. The newly listed companies also fail to increase their capitalization: after rising slightly, the median shareholders' equity returns to the post-RM level three years later (CAN\$1.88 million versus CAN\$1.83 million) and the two distributions do not differ significantly. The median ROE and margin are less negative at year 3 than at year 0 . Globally, the results obtained on the constant sample are very similar to those observed for the whole sample. Even the survivors fail to significantly increase their earnings, and the proportions of companies without revenues or earnings are the same after three years as at the time of the RM. These observations are consistent with proposition 1b: the post-RM operating performance is low, and the companies resulting from RMs exhibit a minimal growth rate.

**Insert Table 5 about here**

\subsection{THE FATE OF THE RESULTING COMPANIES}

We considered as non-surviving (failures) the companies whose stocks were delisted by the exchange, along with failed companies that are not yet delisted and those whose stocks are only traded over the counter. We also extended the analysis of the delisting by detecting and correctly classifying the "living dead" companies. Generally, stock exchanges delist companies whose stocks do not satisfy minimum ongoing requirements based on price, capitalization or volume. During the 
years covered by our analysis, companies that fell below TSXV's ongoing listing standards were designated inactive and given 18 months to meet the standards or be delisted. However, the delisting is not systematic. To align our delisting definition with previous studies, we consider as a failure any stock whose price is below CAN\$0.10 for seven consecutive months. We use the 10cent limit because Canadian IPO prices are, on average, one tenth of prices in the U.S.

Several acquisitions appear to be profitable for the investors, whereas others are clear failures, especially after the burst of the technology bubble. When a merger is mentioned, we assume that the merged company is a continuation of the resulting company. The status is then one of a merged company. For acquisitions, we collected the acquisition price per share (including the value of share exchanges) and qualified as failures the cases where the acquisition price is lower than CAN\$0.10, in line with our definition of living dead in non-merger situations. Most of the RM listings are done on the TSXV. The opportunity to graduate is pivotal in the promotion of actions organized by the exchange to attract new listings. Consistent with the TSXV, we consider that a resulting company succeeds when it graduates to the main exchange, the TSX, or to a foreign exchange.

Table 6 reports the status of resulting companies 10 years (Panel A) or 5 years (Panel B) after the RM, by cohort. After five years, only $66.62 \%$ of RM-listed companies are still present on the exchange, and the proportions of failures and successes are $33.38 \%$ and $4.23 \%$ respectively. We can compare this failure rate with the rate found for IPO listings. In the U.S., Demers and Joos (2007) report a five-year failure rate of 16.7\%. In Canada, Carpentier and Suret (2008) find a nonsurviving rate of $11.60 \%$ after 5 years. Espenlaub et al. (2010) report a delisting rate of $30 \%$ after four to five years on the AIM.

After ten years, $57.63 \%$ of RM-listed companies can be considered failures. A slight proportion of $6.14 \%$ of newly listed companies migrate toward the main exchange. Fama and French (2004) show that the 10-year delisting rate of their sample of small U.S. IPOs is $40.5 \%$. Carpentier and Suret (2008) report a non-surviving rate of $28.29 \%$ after ten years. In Canada, RM listings have produced nine failures per success. The probability of survival of RM-listed companies is low, which is consistent with proposition 1c. However, we cannot perform statistical tests of this trend because the estimation methods and the time of estimation are not the same among the various studies.

**Insert Table 6 about here** 
RM firms exhibit the characteristics of low quality firms. Their operational performance is very low and does not improve after the listing. Their growth rate is minimal, and their survival rate is low compared with rates reported for IPOs in similar studies. The RM market thus looks like a lemon market.

\section{POST-LISTING FINANCING ACTIVITY}

Table 7 summarizes the financing activity of RM-listed firms. If using an RM is part of a financing strategy, we should observe that these firms launch seasoned equity offerings (SEO) after the market has set a price for their stocks. A large proportion of the firms analyzed had no financing activity following the listing. $44.26 \%$ of the firms issue neither private nor public equity. The reasons such companies list are unclear, but they definitely do not list to finance their growth. A proportion of $32.79 \%$ of the companies issue private placements exclusively. In this case as well, the reason for listing is not apparent. Typically, a private company should contemplate a listing to create a public market for its shares, and to ease the exit of private investors. However, if the firm never raises public offerings, its stock liquidity will remain too low for the private investors to exit. About $10 \%$ of the sample obtains private placements on a regular basis (three or more placements). The total financing procured by the 203 firms involved in private placement is low: CAN\$3.5 billion, or CAN\$17.3 million of financing per firm, over an average time frame of 10 years. However, this average is heavily influenced by a few large firms. The median total private placement is CAN\$10 million, if we consider only the firms that launch private placements after an RM.

Less than $23 \%$ of the firms get financing through an SEO, and the mean (median) time elapsed between the RM and the SEO is 11-15 months (3 to 8). These values are close to the 1.1 years $(0.9$ for the median) estimated by Derrien and Kecskes (2007) in their analysis of U.K. two-stage firm offerings. We cannot rule out the possibility that for this subsample of RM-listed companies, the strategy was to reduce the underpricing by letting the market set a price. The average proceeds are CAN\$27.82 million per firm, but the median is CAN\$7 million, indicating the influence of several huge placements and a timid use of the public market.

The majority of RM firms do not list to use the market for the financing of investment projects or to reduce the cost of issuing new shares by creating a liquid secondary market for their stocks. This is in line with proposition 2. 
**Insert Table 7 about here**

\section{Stock Market Performance}

We estimate abnormal returns using the buy-and-hold (BHAR) method, which estimates the return of an investor involved in an RM. To take market fluctuations into account, we reduce the return of each RM firm by that of a portfolio of firms of comparable size and growth expectations. To assess the robustness of our analysis to the choice of the benchmark, we also use the stock market index as a benchmark (S\&P/TSX). Appendix 1 contains the technical description of this estimation, commonly used in similar contexts (Gleason et al., 2006; Locke and Gupta, 2008). We estimate equally-weighted (EW), where an equal weight is given to each firm, and value-weighted (VW) portfolio returns, where weights are proportional to the capitalization. We use both weighting schemes to override the problem induced by the distribution of market capitalizations. The VW results could be largely influenced by a small subsample of large companies.

We report BHAR results for the whole sample in Table 8, Panel A, for the pre- and post-RM periods. ${ }^{16}$ Before the RM, the reported abnormal returns are those of the shell. During the post-RM period we follow the stocks of the resulting company. The abnormal returns for the shell shares are positive and significant during the 12 months preceding the RM announcement. The EW return is $39.47 \%(52.66 \%$ if the S\&P/TSX is the benchmark) and $23.53 \%(24.93 \%)$ if a VW scheme is applied. The differences indicate that the returns are, on average, larger for the smaller shells. However, the large majority of the shell shareholders earn significant positive returns several months before any announcement. The abnormal return is $21.78 \%$ six months before the event. In Canada, several investors seem informed of the transaction several months before the press release related to the RM. The observation of a significant run-up several months before any required announcement has strong implications on the regulatory side. It appears that the actual level and timeliness of the reporting in such transactions is not sufficient to allow all stakeholders to earn a "fair" return.

Post-RM abnormal returns are economically and statistically significant. The three-year average abnormal returns are $-69.77 \%$ and $-44.57 \%$ depending on the benchmark used, on an equally based scheme. VW abnormal returns remain significant and negative, ranging from $-36.43 \%$ to $-37.85 \%$, depending on the benchmark. The difference between the EW and VW return is large, and can be traced to a few large RMs: one raises CAN\$500 million, another CAN\$130 million and, in total, the 
twelve RMs with the largest gross proceeds account for $30 \%$ of the amounts collected around the transaction. Accordingly, the VW results strongly reflect the returns of these twelve transactions that can be excluded from the entrepreneurial venture universe.

Panels B, C and D of Table 8 report the abnormal performance for each group based on the resulting company capitalization. Micro-capitalization companies report capitalization below CAN\$2.8 million. ${ }^{17}$ Compared with the reference portfolio, the abnormal returns are $-102.45 \%$ (EW) to $-115.47 \%(\mathrm{VW})$ for the micro-capitalization companies. Corresponding values are $-61.06 \%$ to $-63.38 \%$ for the small companies and $-46.56 \%$ to $-31.93 \%$ for the larger companies. For these companies, the pre-RM run-up ranges from $34.50 \%$ to $69.22 \%$ depending on the weighting scheme. The possible use of the shell for a large transaction is viewed very positively by the shell owners. The smallest RMs are not preceded by a significant run-up. The novelty of our results is the huge magnitude of the underperformance. The average returns of below $-100 \%$ for the microcapitalization companies indicate that for the majority of investors the stock prices fall to zero while the market or the reference portfolio generates a positive return.

All the results pertaining to stock market performance are consistent with proposition 3: the RM market provides investors with abnormally low returns. This implies that these investors are generally unable to accurately determine the true value and risk of the firms that use this listing method. This situation therefore justifies the implementation of a necessary safeguard for the investors. The observation that publicly traded entrepreneurial ventures provide low returns is consistent with the finding of Locke and Gupta (2008) on the New Zealand market.

**Insert Table 8 about here**

\section{CONCLUSION}

Several researchers and professional associations contend that the securities regulation is too restrictive and unduly impedes the development of new ventures. Concomitantly, regulators and many scholars argue that without strong listing and disclosure requirements, a lemon market will emerge, where only firms of poor quality will list. We analyze these two perspectives in a context of lax minimal requirements where firms can list using an RM with minimal disclosure.

The companies using RMs are predominantly very small, have weak growth, generally provide investors with negative returns and frequently delist. They fail to significantly increase their 
performance and equity size after the listing. This is especially true for the smallest companies, for which the proportion of success is very low compared with the high failure rate. Our results indicate that managers use RMs to list lower quality companies without real growth opportunities, which do not survive in the market. Investing in those firms provides very low rates of return. This indicates that investors fail to accurately appraise the value of RM firms. Our observations are definitely not in line with the propositions that the securities regulation should be changed to allow the financing of entrepreneurial ventures. Our results confirm the lemon proposition stated by Black (2001) and the readiness argument developed by Mason and Harrison (2001).

Our results have implications for regulation and public policies. Even if they have not relaxed the rules up to the Canadian level, several countries have implemented or are contemplating regulatory changes that favor small business financing. This includes several elements of proportionate securities regulation, and the implementation of junior markets devoted to emerging companies. Several stock markets have replaced the rules-based approach that defines thresholds to enter the market by a principles-based approach. RM listings, including those by foreign firms, are becoming common in the U.S., as are the Private Placements in Public Equity. Programs devoted to the creation of shells have been implemented in the U.K. and the U.S. However, small business advocates contend that the regulation is still too restrictive for SMEs. We show that a lemon market can emerge when the rules governing small business equity financing are largely relaxed. A second dimension of our results is also valuable for regulators and policy makers in the area of informal venture capital (Mason, 2009). Individual investors seem unable to correctly invest in small emerging firms. This last result is particularly important because the investors involved in the financing of RM firms are considered by the regulators as "accredited investors." They exhibit considerable revenues or net assets, and they are assumed to be able to invest wisely without the advice of professionals. 


\section{ENDNOTES}

${ }^{1}$ Cohn and Yadley (2007) use this term "small business advocates" to refer to representatives of small businesses who expressed their concerns relative to the Securities and Exchange Commission's negative impact on small business finance, during each of the annual Small Business Forums since 1982. This annual conference between the Securities and Exchange Commission and representatives of small businesses was mandated by Congress in 1980. We extend this term to include academics that endorse similar adjustments.

2 "The SEC's role in capital formation: Help or Hindrance" is available online at:

http://commdocs.house.gov/committees/bank/hba73742.000/hba73742 Of.htm

${ }^{3}$ This expression refers to the seminal paper by Akerlof (1970), who uses the market for used cars as an example of the problem of quality uncertainty. Because of asymmetric information the buyers cannot distinguish between good used cars and defective used cars ("lemons"). Buyers will consequently agree to pay only the price of an average quality car. As a result, sellers of high quality cars will leave the market. Only lemons will be offered, the average market quality will deteriorate and the market will shrink and eventually disappear.

${ }^{4}$ For example, Gleason et al. (2006, p.6) consider 121 RM firms with a median market value of equity of CAN\$50 million (US\$33 million) at the end of the year in which the RM occurs (p.17). We use 892 firms with a median shareholders' equity of CAN $\$ 500,000$ before the listing.

5 The "new" markets in Europe devoted to growing companies generally require minimum gross proceeds of roughly CAN\$8 million (Euro5 million). Several junior markets apply principles-based listing requirements. They do not require a quantitative threshold but the entrant must hire a sponsor. According to Derrien and Kecskes (2007) the average size (gross proceeds) of the IPO firm joining the Alternative Investment Market (AIM) from 1995 to 2004 is CAN\$15 million. On First North, the mean market capitalization was CAN\$85.53 million. In January 2009, the 34 small firms listed on the New Zealand Alternative Exchange had a total capitalization of NZ\$633 million, for an average (post-crisis) capitalization equivalent to CAN\$12.5 million. Even if they use principles rather than rules, these exchanges do not list entrepreneurial ventures at an early stage.

${ }^{6}$ The disclosure requirements for these transactions vary over time and between provinces. In 2005, the exchange modified the policy to require prospectus-like disclosure. We do not consider the intricacy of the various methods or the regulatory dimension of RMs. Interested readers can see Feldman (2009) or Sjostrom (2008) for a detailed presentation of these dimensions.

${ }^{7}$ Accessing the information about the characteristics of the investors is very difficult. We conducted the analysis on a subsample of RMs covering two years. The investors are mainly individual, and do not seem related to the business team. Very few institutional investors are involved, and few investors appear among the important shareholders after the RM. These investors cannot be considered business angels. We have left their characteristics, and rationality, for further studies.

${ }^{8}$ See http://www.reversemergers.net/overview.html or http://www.venturea.com/shell.htm. These economies are largely linked to the non-requirement of a prospectus. When an RM agreement is reached, the company must submit a comprehensive news release. The news release must include a description of the transaction, including a description of the target assets, a summary of any available significant financial information and a description of the terms of the RM. The information the shareholders receive is scant compared with the information required for an IPO.

${ }^{9}$ The total direct costs of new Canadian issues under CAN\$10 million have been estimated about $47 \%$ (Kooli and Suret, 2003). For high-tech ventures seeking external equity finance, Carpentier and Suret (2006) report that the total direct and indirect costs can reach $50 \%$ of the financing round.

${ }^{10}$ See Shane (2003 pp.162-164) for a survey of the empirical evidence of the importance of financial resource acquisition for entrepreneurial ventures. 
${ }^{11}$ The proportionate regulation is the notion that securities regulation should recognize the different risks and benefits of issuers by their size, experience in the market, resources or capacity to act (Sarra, 2009, p. 12). According to this principle, Canadian venture issuers benefit from several regulatory dispositions that limit the costs of regulation, including listing through RM.

${ }^{12}$ This notion is present in the NASDAQ objectives: Given NASDAQ's objective of providing necessary safeguards to public investors in NASDAQ securities, (...) NASDAQ determined to undertake a thorough review of its qualification requirements. In conducting this review, NASDAQ carefully sought to balance its role in facilitating legitimate capital formation for issuers, with NASDAQ's responsibility to provide the appropriate protection to public investors in its markets, NASDAQ Notice to NASD Members, November 1996, http://www.whiteandlee.com/nasdaq.html. Similarly, the Treasury Secretary, Henry M. Paulson, states: We should not engage in a regulatory race to the bottom, seeking to eliminate necessary safeguards for investors in a quest to reduce costs, Remarks on the Competitiveness of U.S. Capital Markets, Economic Club of New York, NY, http://www.ustreas.gov/press/releases/hp174.htm.

${ }^{13}$ The System for Electronic Document Analysis and Retrieval (SEDAR), developed for the Canadian Securities Administrators, is the Canadian equivalent of the U.S. EDGAR system.

${ }^{14}$ Carpentier and Suret (2006) report 1,051 IPOs in Canada (excluding IPOs of CPCs) between 1991 and 2001, and there are 522 RMs during the same period.

${ }^{15}$ Freear et al. (2002, p. 276) define entrepreneurial venture creation as a dynamic process undertaken by entrepreneurs founding high-growth, often technology-based ventures. It is defined less by absolute size, more by growth and the potential for future returns. Commonly, however, entrepreneurial ventures with high growth potential require funding far beyond that supplied by the founders. We consider that the firms in our sample are entrepreneurial ventures and not classical small businesses for the following reasons: by a large majority, they are small, still not profitable and often at a pre-revenue stage; they are closely held before the $\mathrm{RM}$, and the median age since the incorporation is lower than three years. Some of them exhibit a huge growth rate, but a large proportion of these firms will fail, indicating a high level of risk. Most of these firms are seeking for outside equity but the growth rate cannot be sustained by the funds available to the promoter. ${ }^{16}$ Cumulative abnormal return (CAR) results (not reported) are similar and available from the authors.

${ }^{17}$ The estimation of the abnormal returns incorporates several variables, including book-to-market, size and raw returns. We are able to estimate these returns only for 346 observations. The reduction in the sample is more severe for the smaller companies. For the initial sample, the median shareholders' equity is CAN\$1.83 while in the sample available for the return analysis, the first tercile limit of market capitalization is CAN\$2.83 million. 


\section{References}

Adjei, F., K. B. Cyree and M. M. Walker (2007). "The Determinants and Survival of Reverse Mergers versus IPOs." Journal of Economics and Finance 32(2): 176-194.

Akerlof, G. A. (1970). "The Market for "Lemons:" Quality Uncertainty and the Market and Mechanism." The Quarterly Journal of Economics 84: 488-500.

Becchetti, L. and G. Trovato (2002). "The Determinants of Growth for Small and Medium Sized Firms : the Role of the Availability of External Finance." Small Business Economics 19(4): 291-306.

Beck, T. and A. Demirguc-Kunt (2006). "Small and medium-size enterprises: Access to finance as a growth constraint." Journal of Banking \& Finance 30(11): 2931-2943.

Berger, R. (2008). "SPACs: An Alternative Way to Access the Public Markets." Journal of Applied Corporate Finance 20(3): 68-75.

Black, B. S. (2001). "The Legal and Institutional Preconditions for Strong Securities Markets." UCLA Law Review 48: 781-858.

Bottazzi, L. and M. Da Rin (2002). Europe's 'New' Stock Markets. CEPR Discussion Paper 3521

Carpenter, R. E. and B. C. Petersen (2002). "Is the Growth of Small Firms Constrained by Internal Finance?" The Review of Economics and Statistics 84(2): 298-309.

Carpentier, C., J.-F. L'Her and J.-M. Suret (2009). "Stock Exchange Markets for New Ventures." Journal of Business Venturing Forthcoming.

Carpentier, C., R. Labelle, B. Laurent and J.-M. Suret (2008). Does Fair Value Measurement Provide Satisfactory Evidence for Audit? The Case of High Tech Valuation. Working Paper Available at SSRN http://ssrn.com/paper=1269743 http://ssrn.com/paper=1269743

Carpentier, C. and J.-M. Suret (2006). "Bypassing the Financial Growth Cycle: Evidence from Capital Pool Companies." Journal of Business Venturing 21(1): 45-73.

Carpentier, C. and J.-M. Suret (2008). "The Survival and Success of Canadian Penny Stock IPOs." Small Business Economics Forthcoming

Carpentier, C. and J. M. Suret (2006). "Some Evidence of the External Financing Costs of New Technology-based Firms in Canada." Venture Capital : An International Journal of Entrepreneurial Finance 8(2): 227 - 252.

Chen, H., N. Dai and J. Schatzberg (2010). "The Choice of Equity Selling Mechanisms: PIPES versus SEOS." Journal of Corporate Finance 16(1): 104-119.

Chiu, H.-Y. (2004). "Can UK Small Businesses Obtain Growth Capital in the Public Equity Markets? - An Overview of the Shortcomings in UK and European Securities Regulation and Condiderations For Reform." Delaware Journal of Corporate Law 28(3): 933-977.

Cohn, S. and G. Yadley (2007). "Capital Offense: The Sec's Continuing Failure to Address Small Business Financing Concerns." New York University Jounal of Law and Business(4): 1-88.

Cohn, S. R. (1999). "Impact of Securities Laws on Developing Companies: Would the Wright Brothers Have Gotten off the Ground?" Journal of Small and Emerging Business Law 3: 315-366.

Demers, E. A. and P. Joos (2007). "IPO Failure Risk." Journal of Accounting Research 45(2): 333371.

Derrien, F. and A. Kecskes (2007). "The Initial Public Offerings of Listed Firms." The Journal of Finance 62(1): 447-479. 
Espenlaub, S., A. Khurshed and A. Mohamed (2010). Is There Life on the AIM. Working Paper Manchester Business School

Fama, E. F. and K. R. French (2004). "Newly Listed Firms: Fundamentals, Survival Rates, and Returns." Journal of Financial Economics 73(2): 229-169.

Feldman, D. N. (2009). Reverse Mergers and the Other Alternatives to Traditional IPOs. New York, Bloomberg Press

Fenn, G. W., N. Liang and S. Prowse (1997). "The Private Equity Market: An Overview." Financial Markets, Institutions \& Instruments 6(4): 1-106.

Floros, I. V. (2008). Two Essays on Alternative Mechanisms to Going Public. Ph.d Thesis, University of Pittsburgh

Floros, I. V. and K. Shastri (2009). A Comparison of Penny Stock Initial Public Offerings and Reverse Mergers as Alternative Mechanisms to Going Public. Available at SSRN: http://ssrn.com/abstract=1460979

Freear, J., J. E. Sohl and W. Wetzel (2002). "Angles on Angels: Financing Technology-based Ventures--a Historical Perspective." Venture Capital : An International Journal of Entrepreneurial Finance 4(4): 275-287.

Friedman, F. B. and C. Grose (2006). Promoting Access to Primary Equity Markets: A Legal and Regulatory Approach. World Bank Working Paper 3892

Gleason, K. C., R. Jain and L. Rosenthal (2006). Alternatives for Going Public: Evidence from Reverse Takeovers, Self-Underwritten IPOs, and Traditional IPOs. Working Paper, Available at SSRN. http://ssrn.com/abstract=890714

Gleason, K. C., L. Rosenthal and R. A. Wiggins (2005). "Backing into Being Public: an Exploratory Analysis of Reverse Takeovers." Journal of Corporate Finance 12(1): 54-79.

Howorth, C. A. (2001). "Small Firms' Demand for Finance: A Research Note." International Small Business Journal 19(4): 78.

Huffman, J. L. (2000). "The Impact of Regulation on Small and Emerging Businesses." Journal of Small and Emerging Business Law 4(2): 307-317.

Jenkinson, T. and M. Sousa (2009). Why SPAC Investors Should Listen to the Market. AFA 2010 Atlanta Meetings Paper. Available at SSRN: $\underline{\text { http://ssrn.com/abstract=1341771 }}$

Kim, J. (1999). "The Relaxation of Financing Constraints by the Initial Public Offering of Small Manufacturing Firms." Small Business Economics 12(3): 191-202.

Klausner, M. D. and K. Litvak (2001). What Economists Have Taught Us About Venture Capital Contracting. Bridging the Entrepreneurial Financing Gap: Linking Governance with Regulatory Policy. Michael Whincop ed. Burlington: Ashgate: 54-74.

Kooli, M. and J.-M. Suret (2003). "How Cost-Effective are Canadian IPO markets." Canadian Investment Review 16(4): 20-28.

La Porta, R., F. Lopez-De-Silanes and A. Shleifer (2006). "What Works in Securities Laws?" The Journal of Finance 61(1): 1-32.

Locke, S. M. and K. Gupta (2008). "The Performance of Entrepreneurial Companies Post-listing on the New Zealand Stock Exchange." Venture Capital 10(1): 87-110.

Mahérault, L. and B. Belletante (2004). "Does Choosing a Section of the Stock Exchange Matter in the IPO of SMEs? The French Case." Small Business Economics 23(4): 337-348.

Mahoney, P. G. (1995). "Mandatory Disclosure as a Solution to Agency Problems." The University of Chicago Law Review 62(3): 1047-1112.

Martin, T. A. (2001). "The IPO of Young, High Growth SMEs on Neuer Markt." Small Business Economics 16(4): 319-327. 
Mason, C. M. (2009). "Public Policy Support for the Informal Venture Capital Market in Europe: A Critical Review." International Small Business Journal 27(5): 536-556.

Mason, C. M. and R. T. Harrison (2001). "'Investment Readiness': A Critique of Government Proposals to Increase the Demand for Venture Capital." Regional Studies 35(7): 663-668.

Mason, C. M. and R. T. Harrison (2002). "Barriers to Investment in the Informal Venture Capital Sector." Entrepreneurship \& Regional Development 14(3): 271-287.

Moller, R. M. (2000). Securities Regulations and their Effects on Small Business. Report, California Research Bureau, Available at : http://www.library.ca.gov/crb/00/04/00-005.pdf

Posner, E. (2009). The Origins of Europe's New Stock Markets. Cambridge, Harvard University Press.

Roosenboom, P. G. J. and W. L. J. Schramade (2007). Reverse Mergers in the UK: Listed Targets and Private Acquirers. International Mergers \& Acquisitions Activity since 1990: Recent Research and Quantitative Analysis. In G.N. Gregoriou \& L. Renneboog (Eds.). Amsterdam: Elsevier: 113-128.

Rousseau, S. (2000). "The Future of Capital Formation for Small and Medium-sized Enterprises: Rethinking Initial Public Offering Regulation after the Restructuring of Canadian Stock Exchanges." Revue Juridique Thémis 34(3): 659-760.

Sarra, J. (2009). Proportionate Securities Regulation: The Potential for Scaled Treatment of Junior Issuers. Study commissioned by the Expert Panel on Securities Regulation, Available at: http://www.expertpanel.ca/documents/researchstudies/Proportionate\%20Securities\%20Regulation\%20-\%20Sarra.English.pdf

Shane, S. and S. Venkataraman (2000). "The Promise of Entrepreneurship as a Field of Research " Academy of Management Review 25(1): 217-226.

Shane, S. A. (2003). A General Theory of Entrepreneurship. Northampton, MA, E. Elgar

Sjostrom, W. K., Jr. (2008). "The Truth About Reverse Mergers." Entrepreneurial Business Law Journal 2: 743-760.

Westhead, P. and D. J. Storey (1997). "Financial Constraints on the Growth of High Technology Small Firms in the United Kingdom." Applied Financial Economics 7(2): 197-201. 
FIGURE 1 Illustration of the reverse merger listing method.

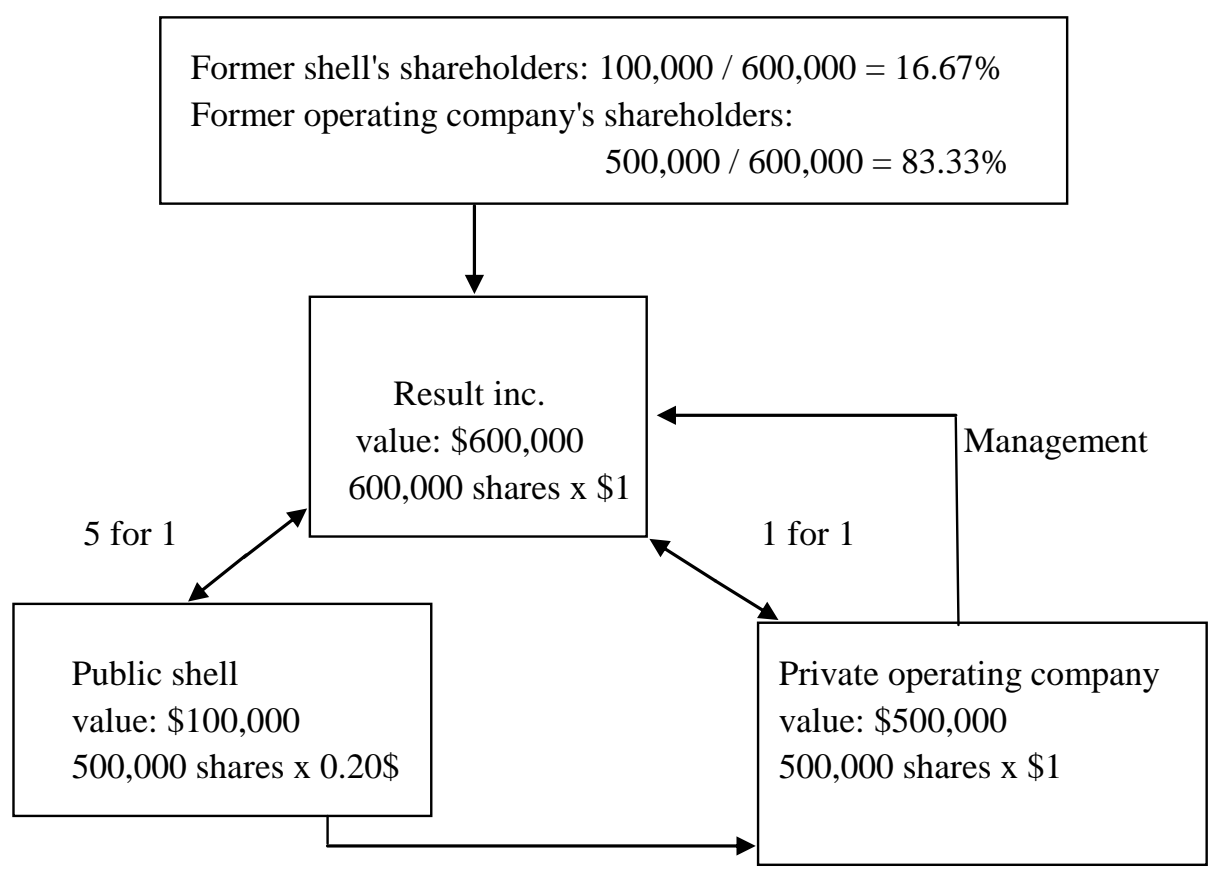

Shell initiates RM 
TABLE 1 Main characteristics of new listings by reverse merger (RM) in Canada, excluding those linked with the Capital Pool Companies Program. Gross proceeds (GP) are the total of the amounts collected at the time of the RM, or during the 12 following months. Stocks issued to acquire the shells are not considered. Gross proceeds are expressed in CAN\$ million $(\$ M)$. $\mathrm{Nb}$ means number of companies.

\begin{tabular}{cccccc}
\hline Year & Nb & Total GP & Mean GP & Median GP & GP $=0$ \\
& & $\$ M$ & $\$ M$ & $\$ M$ & $\%$ \\
\hline $1988-1990$ & 164 & 45.22 & 0.28 & 0.00 & 71.34 \\
$1991-1995$ & 258 & 473.34 & 1.83 & 0.45 & 47.29 \\
$1996-2000$ & 215 & 606.82 & 2.82 & 1.01 & 13.49 \\
$2001-2006$ & 255 & $1,977.90$ & 7.76 & 2.10 & 5.10 \\
\hline $1986-2006$ & 892 & $3,103.29$ & 3.48 & 0.75 & 31.50 \\
\hline
\end{tabular}

TABLE 2 New listing by reverse merger in Canada, by category of gross proceeds (GP), expressed in CAN\$ million $(\$ M)$. Nb means number of companies.

\begin{tabular}{lcccccc}
\hline \multicolumn{1}{c}{$\begin{array}{c}\text { Class of gross } \\
\text { proceeds }\end{array}$} & $\mathrm{Nb}$ & \% Total & Mean $(\$ \mathrm{M})$ & Median $(\$ \mathrm{M})$ & Sum $(\$ \mathrm{M})$ & $\%$ Total \\
\hline $\mathrm{GP}>=\$ 10 \mathrm{M}$ & 66 & 7.40 & 28.94 & 15.00 & $1,910.36$ & 61.56 \\
$\$ 5 \mathrm{M}<=\mathrm{GP}<\$ 10 \mathrm{M}$ & 78 & 8.74 & 6.54 & 6.28 & 510.13 & 16.44 \\
$\$ 1 \mathrm{M}<=\mathrm{GP}<\$ 5 \mathrm{M}$ & 255 & 28.59 & 2.25 & 2.00 & 573.61 & 18.48 \\
$\$ 0.5 \mathrm{M}<=\mathrm{GP}<\$ 1 \mathrm{M}$ & 121 & 13.57 & 0.68 & 0.68 & 82.48 & 2.66 \\
$\mathrm{GP}<\$ 0.5 \mathrm{M}$ & 91 & 10.20 & 0.29 & 0.30 & 26.70 & 0.86 \\
$\mathrm{GP}=0$ & 281 & 31.50 & 0.00 & 0.00 & 0.00 & 0.00 \\
\hline Total: & 892 & 100.00 & 3.48 & 0.75 & 3103.29 & 100.00 \\
\hline
\end{tabular}


TABLE 3 Main characteristics of shells and entrant companies involved in a reverse merger in Canada between 1988 and 2006. Amounts are expressed in CAN\$ million (M\$). Nb means number of companies. EPS means earnings per share. SE means shareholders' equity.

\begin{tabular}{|c|c|c|c|c|c|c|c|c|}
\hline & $\mathrm{Nb}$ & $\%$ & $\begin{array}{l}\text { Median } \\
\text { total assets } \\
\quad(\$ \mathrm{M})\end{array}$ & $\begin{array}{c}\text { Median } \\
\text { SE } \\
(\$ M)\end{array}$ & $\begin{array}{l}\text { Median } \\
\text { Revenues } \\
(\$ \mathrm{M})\end{array}$ & $\begin{array}{l}\text { Median } \\
\text { earnings } \\
(\$ M)\end{array}$ & $\begin{array}{c}\text { Median } \\
\text { ROE } \\
(\%)\end{array}$ & $\begin{array}{c}\text { Median } \\
\text { net Margin } \\
(\%)\end{array}$ \\
\hline \multicolumn{9}{|l|}{ Panel A: Shells } \\
\hline Without revenues & 452 & 67.26 & 0.18 & 0.05 & 0.00 & -0.12 & -41.71 & - \\
\hline With revenues, EPS $<=0$ & 167 & 24.85 & 1.00 & 0.34 & 0.22 & -0.32 & -46.33 & -100.00 \\
\hline With revenues, EPS $>=0$ & 53 & 7.89 & 1.65 & 0.96 & 1.08 & 0.12 & 14.13 & 15.18 \\
\hline Total & 672 & 100.00 & 0.36 & 0.14 & 0.00 & -0.13 & -30.96 & -76.72 \\
\hline Not available & 220 & & & & & & & \\
\hline \multicolumn{9}{|c|}{ Panel B: Entrant companies } \\
\hline Without revenues & 114 & 40.28 & 0.65 & 0.25 & 0.00 & -0.16 & -27.64 & - \\
\hline With revenues, EPS $<=0$ & 103 & 36.40 & 1.94 & 0.26 & 0.59 & -0.62 & -30.58 & -100.00 \\
\hline With revenues, EPS $>=0$ & 66 & 23.32 & 2.83 & 0.63 & 3.48 & 0.20 & 19.75 & 9.49 \\
\hline Total & 283 & 100.00 & 1.27 & 0.35 & 0.09 & -0.13 & -11.29 & -15.25 \\
\hline Not available & 609 & & & & & & & \\
\hline
\end{tabular}

TABLE 4 Adjusted return on assets (ROA) and adjusted return on equity (ROE) of the entrant companies involved in a reverse merger in Canada between 1988 and 2006. ROA (ROE) is net income divided by total assets (shareholders' equity). The adjusted performance of a firm is estimated by its raw return minus the median ratio of its size and sector matching group.

\begin{tabular}{ccc}
\hline & Adjusted ROA & Adjusted ROE \\
\hline Number & 557 & 470 \\
Mean & $-13.36 \%$ & $-6.15 \%$ \\
t value & $-4.27 * * *$ & $-1.69^{*}$ \\
\hline
\end{tabular}

*** significant at $1 \%$ level; ** significant at $5 \%$ level; * significant at $10 \%$ level. 
TABLE 5 Changes in operational characteristics of companies listed by reverse merger in Canada. In year -1, we compute the sum of the revenues, earnings and total assets of the shell and of the entrant company. Numbers for years 0 to 3 are those of the resulting companies. All amounts are expressed in CAN\$ million (\$M). SE means shareholders' equity. Nb means number of observations. $\mathrm{P}$ value from Wilcoxon Signed-rank test for change in variable ( $p$ value of $z$ test of comparison of proportions) from year $\mathrm{i}$ to year $\mathrm{j}$.

\begin{tabular}{|c|c|c|c|c|c|c|c|c|}
\hline \multirow[b]{2}{*}{ Year } & \multicolumn{4}{|c|}{ Whole sample } & \multicolumn{4}{|c|}{ Constant sample } \\
\hline & $\begin{array}{l}\text { Median } \\
\text { Revenues } \\
(\$ M)\end{array}$ & $\begin{array}{c}\% \\
\text { without } \\
\text { revenues }\end{array}$ & $\begin{array}{c}\text { Median } \\
\text { earnings } \\
(\$ M)\end{array}$ & $\begin{array}{c}\% \\
\text { negative } \\
\text { earnings }\end{array}$ & $\begin{array}{l}\text { Median } \\
\text { Revenues } \\
(\$ \mathrm{M})\end{array}$ & $\begin{array}{c}\% \\
\text { without } \\
\text { revenues }\end{array}$ & $\begin{array}{c}\text { Median } \\
\text { earnings } \\
(\$ M)\end{array}$ & $\begin{array}{c}\% \text { negative } \\
\text { earnings }\end{array}$ \\
\hline-1 & 0.15 & 40.28 & -0.23 & 69.61 & 0.10 & 42.06 & -0.15 & 64.29 \\
\hline 0 & 0.22 & 33.66 & -0.50 & 80.30 & 0.20 & 34.12 & -0.39 & 80.42 \\
\hline 1 & 0.40 & 32.53 & -0.73 & 79.85 & 0.46 & 32.94 & -0.63 & 79.23 \\
\hline 2 & 0.45 & 33.62 & -0.61 & 79.70 & 0.48 & 33.83 & -0.48 & 78.04 \\
\hline \multirow[t]{2}{*}{3} & 0.40 & 34.47 & -0.58 & 78.42 & 0.61 & 32.94 & -0.54 & 77.45 \\
\hline & $\mathrm{p}$ value & $\mathrm{p}$ value & $\mathrm{p}$ value & $\mathrm{p}$ value & $\mathrm{p}$ value & $\mathrm{p}$ value & $\mathrm{p}$ value & $\mathrm{p}$ value \\
\hline $0 ; 1$ & 0.11 & 0.34 & $0.02 * *$ & 0.43 & 0.12 & 0.37 & $0.04 * *$ & 0.35 \\
\hline $0 ; 2$ & $0.04 * *$ & 0.49 & $0.08^{*}$ & 0.40 & $0.03 * *$ & 0.47 & 0.18 & 0.22 \\
\hline $0 ; 3$ & $0.04 * *$ & 0.60 & 0.45 & 0.24 & $0.01 * * *$ & 0.37 & 0.12 & 0.17 \\
\hline Year & $\begin{array}{c}\text { Median } \\
\text { SE } \\
(\$ M)\end{array}$ & $\begin{array}{c}\text { Median } \\
\text { ROE } \\
(\%)\end{array}$ & $\begin{array}{c}\text { Median } \\
\text { net margin } \\
(\%)\end{array}$ & $\mathrm{Nb}$ & $\begin{array}{c}\text { Median } \\
\text { SE } \\
(\$ M) \\
\end{array}$ & $\begin{array}{c}\text { Median } \\
\text { ROE } \\
(\%)\end{array}$ & $\begin{array}{c}\text { Median } \\
\text { net margin } \\
(\%)\end{array}$ & $\mathrm{Nb}$ \\
\hline-1 & 0.50 & -16.66 & -28.24 & 283 & 0.44 & -16.22 & -7.45 & 126 \\
\hline 0 & 1.83 & -20.12 & -43.47 & 609 & 1.48 & -18.94 & -36.82 & 337 \\
\hline 1 & 1.85 & -21.48 & -44.22 & 541 & 1.27 & -18.87 & -34.05 & 337 \\
\hline 2 & 2.22 & -17.77 & -36.40 & 473 & 1.75 & -14.01 & -23.50 & 337 \\
\hline \multirow[t]{2}{*}{3} & 1.88 & -15.31 & -28.12 & 380 & 1.83 & -15.12 & -24.56 & 337 \\
\hline & $\mathrm{p}$ value & $\mathrm{p}$ value & $\mathrm{p}$ value & & $\mathrm{p}$ value & $\mathrm{p}$ value & $\mathrm{p}$ value & \\
\hline $0 ; 1$ & 0.55 & 0.93 & 0.65 & & 0.47 & 0.97 & 0.54 & \\
\hline $0 ; 2$ & 0.91 & 0.64 & 0.40 & & 0.98 & 0.35 & 0.17 & \\
\hline $0 ; 3$ & 0.29 & 0.31 & $0.06^{*}$ & & 0.83 & 0.49 & $0.10^{*}$ & \\
\hline
\end{tabular}

*** significant at $1 \%$ level; ** significant at $5 \%$ level; * significant at $10 \%$ level. 
TABLE 6 Status of the companies following a reverse merger, after 10 years (Panel A) and 5 years (Panel B).

\begin{tabular}{cccccccc}
\hline \multirow{2}{*}{ Year } & \multicolumn{2}{c}{ Surviving, successful } & \multicolumn{2}{c}{ Surviving, unsuccessful } & \multicolumn{2}{c}{ Non-surviving } & Total \\
\cline { 2 - 7 } & $\mathrm{Nb}$ & $\%$ & $\mathrm{Nb}$ & $\%$ & $\mathrm{Nb}$ & $\%$ & $\mathrm{Nb}$ \\
\hline \multicolumn{2}{l}{ Panel A: } & Sample restricted to RM prior to & 1997-01-01 & (10 years) & & & \\
\hline 1988 & 1 & 1.59 & 20 & 31.75 & 42 & 66.67 & 63 \\
1989 & 2 & 2.99 & 25 & 37.31 & 40 & 59.70 & 67 \\
1990 & 4 & 11.76 & 13 & 38.24 & 17 & 50.00 & 34 \\
1991 & 1 & 2.94 & 18 & 52.94 & 15 & 44.12 & 34 \\
1992 & 3 & 5.45 & 22 & 40.00 & 30 & 54.55 & 55 \\
1993 & 5 & 7.35 & 25 & 36.76 & 38 & 55.88 & 68 \\
1994 & 3 & 5.77 & 16 & 30.77 & 33 & 63.46 & 52 \\
1995 & 5 & 10.20 & 15 & 30.61 & 29 & 59.18 & 49 \\
1996 & 5 & 10.00 & 17 & 34.00 & 28 & 56.00 & 50 \\
Total & 29 & 6.14 & 171 & 36.23 & 272 & 57.63 & 472 \\
\hline Panel B: Sample restricted to RM prior to $2002-01-01(5$ years) & & & \\
\hline 1988 & 0 & 0.00 & 35 & 55.56 & 28 & 44.44 & 63 \\
1989 & 2 & 2.99 & 44 & 65.67 & 21 & 31.34 & 67 \\
1990 & 3 & 8.82 & 20 & 58.82 & 11 & 32.35 & 34 \\
1991 & 0 & 0.00 & 29 & 85.29 & 5 & 14.71 & 34 \\
1992 & 1 & 1.82 & 46 & 83.64 & 8 & 14.55 & 55 \\
1993 & 4 & 5.88 & 40 & 58.82 & 24 & 35.29 & 68 \\
1994 & 3 & 5.77 & 35 & 67.31 & 14 & 26.92 & 52 \\
1995 & 3 & 6.12 & 41 & 83.67 & 5 & 10.20 & 49 \\
1996 & 3 & 6.00 & 34 & 68.00 & 13 & 26.00 & 50 \\
1997 & 2 & 4.88 & 26 & 63.41 & 13 & 31.71 & 41 \\
1998 & 0 & 0.00 & 23 & 60.53 & 15 & 39.47 & 38 \\
1999 & 1 & 3.45 & 13 & 44.83 & 15 & 51.72 & 29 \\
2000 & 4 & 7.02 & 23 & 40.35 & 30 & 52.63 & 57 \\
2001 & 3 & 6.12 & 19 & 38.78 & 27 & 55.10 & 49 \\
Total & 29 & 4.23 & 428 & 62.39 & 229 & 33.38 & 686 \\
\hline
\end{tabular}


TABLE 7 Summary of the financing activity of firms resulting from a reverse merger (RM), from the RM date to December, 2006.

\begin{tabular}{lccccc}
\hline \# of firms & $\%$ & $\begin{array}{c}\text { Mean time } \\
\text { in months }\end{array}$ & $\begin{array}{c}\text { Median time } \\
\text { in months }\end{array}$ & $\begin{array}{c}\text { Total gross proceeds } \\
\text { in CAN\$ million }\end{array}$ \\
\hline $\begin{array}{l}\text { No financing } \\
\text { Private placements }\end{array}$ & 274 & 44.26 & - & - & - \\
$\quad$ f financing & 91 & 14.70 & 28.06 & 13.86 & 868.54 \\
2 financings & 53 & 8.56 & 18.17 & 10.51 & 779.16 \\
3 financings & 27 & 4.36 & 14.14 & 5.75 & 525.12 \\
>=4 financings & 32 & 5.17 & 17.15 & 6.97 & $1,339.24$ \\
$\quad$ Total & 203 & 32.79 & 21.91 & 9.40 & $3,512.05$ \\
Seasoned public offerings & & & & & \\
$\quad$ f financing & 95 & 15.35 & 19.95 & 7.82 & $1,098.37$ \\
2 financings & 21 & 3.39 & 10.85 & 2.40 & $1,061.27$ \\
3 financings & 13 & 2.10 & 15.16 & 8.48 & $1,110.18$ \\
>=4 financings & 13 & 2.10 & 7.49 & 3.32 & 680.43 \\
$\quad$ Total & 142 & 22.94 & 17.02 & 6.80 & $3,950.25$ \\
All RM & 619 & 100.00 & & & \\
\hline
\end{tabular}


TABLE 8 Abnormal returns of companies resulting from a reverse merger (RM). Abnormal returns are computed as Buy-and-Hold Abnormal Returns (BHAR) relative to size/book-to-market reference portfolios (reference portfolio) or to the S\&P/TSX index. Panel A presents the whole sample, for which market data are available. Panel B, C and D present the sample restricted respectively to the micro-cap, small sized and larger sized resulting companies. The size is estimated using tercile of post-listing market capitalizations. $\mathrm{Nb}$ means number of observations. Amounts are expressed in CAN\$ million (\$M).

\begin{tabular}{|c|c|c|c|c|c|c|}
\hline & \multicolumn{3}{|c|}{$\begin{array}{l}\text { Abnormal returns, } \\
\text { Reference portfolio }\end{array}$} & \multicolumn{3}{|c|}{$\begin{array}{l}\text { Abnormal returns, } \\
\text { S\&P/TSX index }\end{array}$} \\
\hline & $\mathrm{Nb}$ & $\begin{array}{c}\text { BHAR, } \\
\text { Mean, equally } \\
\text { weighted, in \% }\end{array}$ & $\begin{array}{c}\text { BHAR, } \\
\text { Mean, value } \\
\text { weighted, in \% }\end{array}$ & $\mathrm{Nb}$ & $\begin{array}{c}\text { BHAR, } \\
\text { Mean, equally } \\
\text { weighted, in \% }\end{array}$ & $\begin{array}{c}\text { BHAR, } \\
\text { Mean, value } \\
\text { weighted, in \% }\end{array}$ \\
\hline \multicolumn{7}{|l|}{ Panel A Whole sample } \\
\hline Pre listing $(-12 ;-1)$ & 177 & 39.47 & 23.53 & 177 & 52.66 & 24.93 \\
\hline t value & & $4.83 * * *$ & $3.41 * * *$ & & $6.18 * * *$ & $3.50 * * *$ \\
\hline Post-listing $(+1,+36)$ & 346 & -69.77 & -37.85 & 346 & -44.57 & -36.43 \\
\hline $\mathrm{t}$ value & & $-9.97 * * *$ & $-5.93 * * *$ & & $-7.88 * * *$ & $-6.30 * * *$ \\
\hline \multicolumn{7}{|c|}{ Panel B Micro-cap companies (post-listing market capitalization $\$ 2.83 \mathrm{M}$ ) } \\
\hline Pre listing $(-12 ;-1)$ & 42 & 0.90 & -50.51 & 42 & 16.65 & -48.55 \\
\hline t value & & 0.07 & $-5.02 * * *$ & & 1.23 & $-4.36 * * *$ \\
\hline Post-listing $(+1,+36)$ & 111 & -102.45 & -115.47 & 111 & -51.46 & -68.13 \\
\hline $\mathrm{t}$ value & & $-7.35 * * *$ & $-9.47 * * *$ & & $-4.80 * * *$ & $-7.54 * * *$ \\
\hline \multicolumn{7}{|c|}{ Panel C Small-sized companies ( $\$ 2.83 \mathrm{M}<=$ post-listing market capitalization $<\$ 11.85 \mathrm{M}$ ) } \\
\hline Pre listing $(-12 ;-1)$ & 67 & 33.86 & 2.69 & 67 & 45.46 & 3.76 \\
\hline t value & & $2.88 * * *$ & 0.29 & & $3.45^{* * *}$ & 0.38 \\
\hline Post-listing $(+1,+36)$ & 126 & -61.06 & -63.38 & 126 & -38.54 & -48.60 \\
\hline $\mathrm{t}$ value & & $-5.11 * * *$ & $-5.25 * * *$ & & $-3.88 * * *$ & $-4.86 * * *$ \\
\hline \multicolumn{7}{|c|}{ Panel D Larger-sized companies (post-listing market capitalization $>=\$ 11.85 \mathrm{M}$ ) } \\
\hline Pre listing $(-12 ;-1)$ & 68 & 69.22 & 34.50 & 68 & 81.95 & 35.93 \\
\hline t value & & $4.61 * * *$ & $3.08 * * *$ & & $5.33 * * *$ & $3.11 * * *$ \\
\hline Post-listing $(+1,+36)$ & 109 & -46.56 & -31.93 & 109 & -44.53 & -37.42 \\
\hline t value & & $-4.94 * * *$ & $-2.73 * * *$ & & $-5.24 * * *$ & $-3.51 * * *$ \\
\hline
\end{tabular}

*** significant at $1 \%$ level; ** significant at $5 \%$ level; * significant at $10 \%$ level. 
APPENDIX 1: Estimation of abnormal returns

We estimate abnormal returns using the BHAR method the following way. The returns are estimated against reference portfolios composed of companies of comparable size and book-tomarket ratio. To construct the reference portfolios, we extract Canadian firms' book-equity from the accounting database and estimate the book-to-market ratios after matching the stock market and accounting databases. To construct the size control portfolio, all Canadian stocks are ranked each month according to their market capitalization and three portfolios are formed. Independently, all Canadian stocks are also ranked according to their book-to-market ratios and three portfolios are formed. The returns of the nine monthly rebalanced portfolios are calculated as the value-weighted average of the individual-firm monthly returns in each of the size/book-to-market intersections. Each RM firm is then assigned a control portfolio based on its market capitalization and book-tomarket ratio over the performance test period examined. BHARs is based on the calculation of the average abnormal return from a buy-and-hold strategy $\left(\overline{B H A R}_{1 \text { to } q}\right)$ from the RM month (1) to the month $\mathrm{q}(36)$, using $\mathrm{w}_{\mathrm{i}}$, the weight of the stock $\mathrm{i}$ in forming the average holding period return.

$$
\overline{\text { BHAR }_{1 \text { to } q}}=\sum_{i=1}^{N q} w_{i, q} \text { BHAR }_{i, 1 \text { to } q} \text {, where } \mathrm{BHAR}_{\mathrm{i}, 1 \text { toq }}=\prod_{s=1}^{q}\left(1+R_{i, s}\right)-\prod_{s=1}^{q}\left(1+R_{b i, s}\right)
$$

Thus, BHARs measure the average multiyear returns $\left(\mathrm{R}_{\mathrm{i}}\right)$ from a strategy of investing in all Canadian RM-listed firms, and selling at the end of a particular holding period, versus a comparable strategy using a benchmark $\left(R_{b i}\right)$. BHARs are similarly estimated for the $[-12,-1]$ months before the RM. 